India (1898), Georgia (1900), Spain (1905), Flint Island (1908), Kiev (1914), Washington (1918) and West Australia (1922), where he obtained results confirming the theoretical value of the Einstein effect. Apart from this, Campbell's main contribution was to the study of the flash spectrum by means of a spectrograph provided with a slit and moving plate, by which the height of the exciting elements in the reversing layer could be accurately recorded. His preparations for an eclipse expedition were a model of organization.

So conspicuous were these powers of organization and administration that Campbell was persuaded in 1923 to become president of the University of California, a position which he retained until 1930 without giving up the control of the Lick Observatory. These were years of notable expansion in the University, which is now perhaps the largest in the world, having more than 15,000 students resident at Berkeley and a total enrolment with other local centres exceeding 24,000. After retirement from the University and from the direction of the Observatory in 1930, Campbell became president of the National Academy of Sciences (1931-35).

Campbell's astronomical writings will be found for the most part in the publications of the Lick Observatory. His "Elements of Practical Astronomy" (1899) is an unpretentious work, which many students must have found useful. His "Stellar Motions", which was published in 1913, brings together in an attractive form that part of astronomy to which his own researches had made so large and important a contribution.

In addition to numerous academic honours, Campbell received the gold medal of the Royal Astronomical Society in 1906, both the Lalande and the Janssen Medals from the Paris Academy of Sciences, and the Bruce Medal in 1915. As president of the International Union of Astronomy in 1922-25, he presided over the Cambridge meeting of that body. In the same year, 1925, he delivered the Halley Lecture at Oxford.

The opening years of the present century witnessed a notable expansion in the methods and outlook of astronomy. In this development Campbell played an outstanding part. His character was energetic and forceful, and his successful career can be attributed to a perfect harmony between his considerable powers and the researches which the circumstances of the time led him to undertake. An English fellow in the Lick Observatory cannot fail to add a tribute to his unfailing kindness, and the practical help which he was always ready to give. His sense of duty was outstanding. When, after recovering from the serious illness which brought his services to the University of California to an end, he became president of the National Academy of Sciences, he might have looked forward to an honourable period of comparative leisure at Washington. But it was not to be. The condition of national affairs led the Government to appeal to the Academy for help in a great variety of problems. In dealing with these Campbell did not spare himself, with the result that these years of office, so far from bringing dignified ease, were perhaps even more strenuous than any in his busy life. In him has passed away not only a great astronomer whose name will remain in the history of the science, but also one who was no less conspicuous in the public service of his country.

H. C. P.

\section{Dr. Alexander Galt}

Dr. Alexander GaLt, whose death at the age of eighty-three years occurred on June 26, was appointed keeper of the Technological Department, the Royal Scottish Museum, Edinburgh, in 1901, the year in which the Department was founded. He graduated at the University of Glasgow where he was a Thomson (Lord Kelvin) scholar in physical science, and a Donaldson scholar in natural science. For eight years he was official assistant to Lord Kelvin in Glasgow University. Among his publications were papers on physics and physical chemistry in the Proceedings and Transactions of the Royal Societies of London and Edinburgh. $\mathrm{He}$ was external Examiner in Experimental Physies for degrees in Arts and Science in the University of Edinburgh in 1910-14.

Soon after the Royal Scottish Museum came under the control of the Scottish Education Department, the new post of keeper of the Department of Technology was offered to Dr. Galt. The inauguration of this Department was really a reversion to the original purpose of the Museum, founded in 1854, under the name of the "Industrial Museum of Scotland". Dr. Galt had no previous experience of museum work, although he had the important qualifications of a large educational experience, a scientific training and a wide and intimate knowledge of science, and its application to industry.

While the work of organizing the Department was one of exceptional difficulty, it offered great opportunities to Dr. Galt's creative abilities. After careful study of the problem it was decided to illustrate, by means of models and specimens, the great industries of general engineering, coal mining, and the manufacture of iron and steel. Other branches of science and industry were added later and the scope of the collections was extended.

Under Dr. Galt's personal supervision many very fine working models of engineering, mining, and other interest were constructed in the Museum workshops, and added to the growing collections, which are to-day of world-wide repute.

\section{Miss Edith Stoney}

The British Federation of University Women has suffered a great loss in the death, on June 25, at the age of sixty-nine years, of Miss Edith Stoney who, on the day of her death, had been elected one of its vice-presidents. Edith Stoney was a member of a distinguished Irish family of scientific workers; her father, an uncle and a brother all being fellows of the Royal Society, whilst her sister, Dr. Florence Stoney, was one of the pioneers of $\mathrm{X}$-ray work in medicine.

Edith herself was a mathematical physicist. As a student of Newnham College in 1890-94 she took 
both parts of the Mathematical Tripos, being bracketed equal to the seventeenth wrangler in Part I. She also had charge of the telescope at Newnham. After leaving Cambridge she became head of the Physics Department in the London (Royal Free Hospital) School of Medicine for Women, a post which she resigned in 1915 to take up war work. She joined the Scottish Women's Hospitals and served first in the Tent Hospital at Troyes where she put up and ran the X-ray Department, and afterwards in Serbia, where the unit was ordered by the French authorities. Later she became lecturer in physics at the King's College for Household and Social Science.

Edith Stoney travelled considerably, and a visit to Australia convinced her of the need for visits from Great Britain to the Dominions. She supported these views practically and generously by her gifts to the British Federation of University Women of research studentships in science to enable younger women graduates of the universities of Great Britain and Ireland, who were also members of the Federation, to go to these countries. She was so pleased with the success of her first scholars in Australia and New Zealand that this year she gave a sixth studentship, this time to be held in South Africa, to which the award was made at a meeting attended by Miss Stoney only a week before she died. The subjects of the studentships awarded included biochemistry, zoology (insect parasites) and botany. It is learned that in her will she has left money to the Federation for the continuance of these Johnstone and Florence Stoney Studentships. Her association with the Federation has been a great stimulus and pleasure to her fellow-members, who will be deeply sensible of the loss they have sustained in her death.

\section{Prof. Rudolf Vondráček}

By the death of Prof. R. Vondráček at Brno on June 12, Czechoslovakia has lost a distinguished chemist and technologist. Vondráček began his career as a research worker in pure and applied chemistry whilst completing his studies under Prof. Votoček at Prague, with whom he investigated the separation of certain reducing sugars by hydrazine. Altogether he contributed about fifty original papers to Central European periodicals and he was the author of four text-books.

After a period spent in the laboratories of industrial concerns and during which his researches related mainly to analytical methods, Vondráček spent some time before and during the Great War as an examiner for the Austrian Patent Office in Vienna. In December 1918 he returned to Czechoslovakia to take up the appointment as professor of chemistry at the Brmo Polytechnic, a post he held until his death. During this time he was twice dean (1920-21 and 1930-31) and he filled the office of rector during the session 1935-36.

His most important researches are connected with a study of the corrosion of metals and with the chemistry and physics of fuel technology. He made careful investigations into the calorific value of various fuels and directed attention to certain anomalies in fuel analysis such as the variation in the estimated water content, an apparently greater loss being recorded at $100^{\circ} \mathrm{C}$. than at $105^{\circ} \mathrm{C}$. He noticed, too, a 'timelag' in the absorption of moisture by coal.

Prof. Vondráček was an authority on the destructive distillation of fuels at low temperature, for the experimental study of which he used a bath of boiling sulphur. He carried out analyses of the gases evolved by the Czechoslovak petroleum springs at Gbely and succeeded in removing carbon monoxide and unsaturated hydrocarbons from the gas, which is used locally for lighting and heating. Even his physicochemical researches had some bearing upon industrial technology. Thus, almost his last work was a study of the binary systems of phenol with hydrocarbons. $\mathrm{He}$ found, among other things, that phenol is a suitable reagent for the separation of hydrocarbon mixtures, being preferable to such means as nitration or bromination.

$\mathrm{He}$ was a member of many continental scientific societies and was prominent in the activities of the Masaryk Academy of Work.

G. D.

\section{Mr. A. W. Shorter}

WE regret to record the death of $\mathrm{Mr}$. A. W. Shorter, assistant keeper in the Department of Egyptian and Assyrian Antiquities of the British Museum (Bloomsbury), which took place on May 31 at the age of thirty-two years.

Alan Wynn Shorter was the son of Mr. Wilfrid Wynn Shorter, and was educated at St. Paul's School and Queen's College, Oxford, where he graduated in 1928. Before taking his degree he had for some time devoted himself to the study of Egyptology, and more especially to the study of the religious beliefs and rituals of the ancient Egyptians, as set forth in "The Book of the Dead". On leaving Oxford in 1928-9 he spent a year working on the excavations of the Egypt Exploration Society at Tell el-Amarna; and on his return to England he secured an appointment on the staff of the British Museum. Here in the Department of Egyptian Antiquities he was able to continue his study of the material culture, arts and religion of the ancient Egyptian people. He was the author of a number of popular books on these subjects, and also contributed to the publications of learned societies, specializing in the study of Egyptian papyri. His principal contribution to Egyptology is a "Catalogue of Egyptian Religious Papyri in the British Museum".

Wr regret to announce the following deaths :

Prof. R. M. Bird, professor of organic chemistry in the University of Virginia, on June 4, aged seventyone years.

Dr. B. T. Galloway, formerly pathologist in the U.S. Bureau of Plant Industry, on June 13, aged seventy-four years.

Sir Colin Mackenzie, formerly director of the Australian Institute of Anatomy, aged sixty-one years.

Mr. H. N. Thompson, C.M.G., lately director of forests, Nigeria, on July 9. 